\title{
ASSESSMENT OF FORMATION OF STUDENTS' SOFT SKILLS IN HIGHER EDUCATION
}

\section{Hanna Sereda ${ }^{1}$}

DOI: https://doi.org/10.30525/978-9934-588-84-6-7

The formation and development of universal flexible skills, called in educational and professional fields as Soft Skills is one of the key tasks of higher education. At the World Economic Forum 2020 in Davos, the importance of developing flexible universal skills for the readiness of the workforce to develop a new economy, in which artificial intelligence, work, AR and VR, digital production and services has already become a reality. Among the skills needed by employers from all industries in 2015-2020, the complex problem-solving skills (36\%), social skills (19\%), process skills (18\%), system skills (17\%), cognitive came to the fore in terms of business demand. abilities (15\%). Hard skills rank at the bottom of this list: physical abilities are only needed by $4 \%$ of employers, content skills by $10 \%$, and technical skills by $12 \%$ [1].

Concidering the need for the formation of Soft Skills in the system of higher education of specialists in the agricultural sector and development, Hagmann and Almekinders et al. (2003) describe two cases from introducing personal mastery learning workshop in a $\mathrm{PhD}$ program at Wageningen Agricultural University and Research in 2002 and two-year long learning process on personal mastery for research, training, and consultancy, involving university lecturers at Makerere University in Uganda. In the first case, doctoral students after a nine-month course of theoretical training were invited to conduct research in the fields to collect data for dissertation research. However, a special pilot 10-days personal possession workshop was previously held for 17 research candidates in addition to the general training, which was developed and implemented by two external process consultants / facilitators in October 2002. Among the important conclusions made in the first case by its participants were: changing the emphasis in research on theoretical focuses and applied research, the results of which will be of interest to farmers and fellow teachers; improving the facilitation skills of participants as a prerequisite for increasing student involvement in the learning process. In another case

\footnotetext{
${ }^{1}$ Vasyl’ Stus Donetsk National University, Ukraine
} 
at Makerere University in Uganda the learning process was designed as a sequence of workshops with practice periods in between. The program consists of competence in facilitation, teaching / training, advisory / consulting skills, personal development, etc. The results of implementing have been way beyond expectations. It consisted of strengthening feedback and interaction skills at the personal level, improving interactive teaching skills, facilitation in learning and in staff relationships [2].

In Ukraine, one of the 4 key goals of higher education, defined in the legislation, is to promote the personal development of students, which is ensured by the formation of soft skills. In the procedures of accreditation of educational programs, the National Agency for Quality of Higher Education of Ukraine checks how the educational program envisages the acquisition of soft skills by students that meet the stated goals.

In Vasyl' Stus Donetsk National University as an implementation of the results of the EU project «Tempus Impress» («Improving the efficiency of student services») 2012-2015 has been developed and implemented in the educational process the special learning course on «Training Soft Skills «(3 credits of ECTS, 30 hours in classroom) for 3 -year students of the Faculty of Economics. The course consists of 3 parts:

1) Self-management and personal efficiency skills (30\%): goals setting, development of Personal Development Plan, time-management tools, self-motivation theories and practices;

2) Interpersonal Skills (50\%): communication skills (10\%), presentation skills (10\%), academic debate (15\%), group work $(15 \%)$, peer-to-peer interaction (10\%);

3) Learning skills (20\%): critical thinking development (10\%), reflective thinking and writing (10\%).

Assessment of student performance was carried out as follows:

1) Formative assessment - specific feedback on interview and associated paperwork to support placement application; advice and guidance on progress of personal and professional development planning;

2) Summative assessment consists of 2 parts: the final assessment creating a reflective essay backed up by a PDP; a middle point assessment which is an academic debate featuring 'for' / 'against' and objective observation.

When implementing the course in 2015, we were faced with the question of long-term assessment of acquired skills and application in their life and the career. The Four Levels of Learning Evaluation Model by Donald Kirkpatrick can be successfully used to assess learning 
effectiveness. Level 1 Reaction measures how participants react to the training (by scale or questionnaire about students' satisfaction). Level 2 Learning analyzes of increase in knowledge, skills or experience. Level 3 Behavior looks at if they are utilizing what they learned at work (change in behaviors), and Level 4 Results determines if the material had a positive impact on the business / organization [3].

Survey of students on satisfaction with the course showed a high level of quality of the discipline, its content, structure and teaching methods: $91 \%$ of respondents rated the course at a high level [4, p. 179].

For assessment at the second level, the use of formative and summative assessment methods was sufficient. The greatest expediency for the formation of soft skills is to assess changes in the behavior of students in the long term. To perform this task, a questionnaire with markers of some clusters of Soft skills was developed, it contains 10 markers of time management skills, 20 markers of other self-management skills, 16 questions to assess communication skills (fragment of the questionnaire look at the Table 1).

To ensure the purity of the research, the survey was conducted at the beginning of the training course (35 students were interviewed) and a year later (after six months of studing). The results of the survey showed the largest increase in time management and self-organization skills (Figure 1).

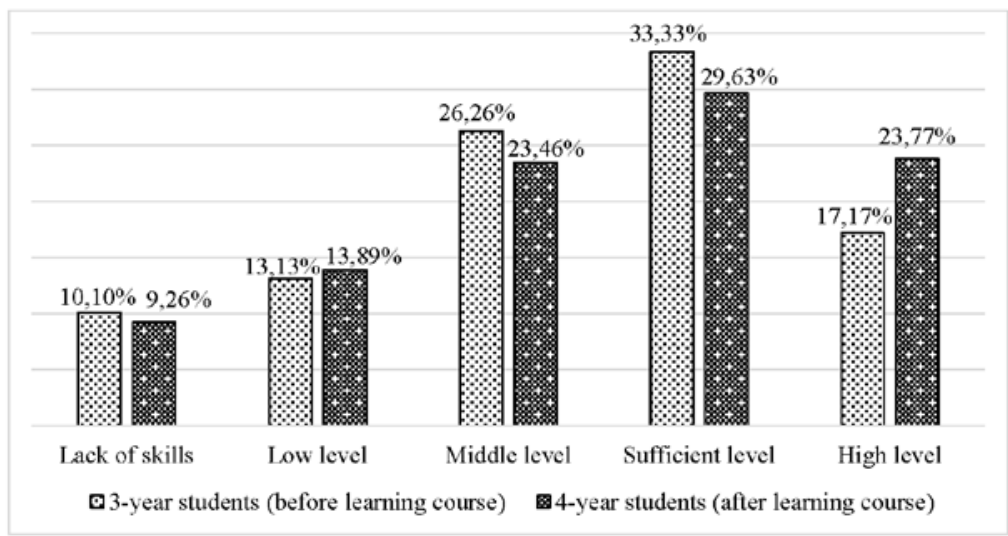

Figure 1. Changes in students' self-management skills before and after studying the Training Soft Skills course

Source: developed by the author 
Table 1

\section{Questionnaire on self-assessment of Soft Skills (fragment)}

\begin{tabular}{|c|c|c|c|c|c|c|}
\hline Markers of time-management skills & Never & Rarely & $\begin{array}{l}\text { Some- } \\
\text { times }\end{array}$ & Often & \multicolumn{2}{|c|}{ Always } \\
\hline \multicolumn{7}{|l|}{$\begin{array}{l}\text { I regularly (once a year / half a } \\
\text { year) set realistic goals for myself, } \\
\text { and monitor progress until I reach } \\
\text { them }\end{array}$} \\
\hline \multicolumn{7}{|l|}{$\begin{array}{l}\text { I develop plans to achieve my } \\
\text { goals envisaging necessary time } \\
\text { and other resources }\end{array}$} \\
\hline \multicolumn{7}{|l|}{$\begin{array}{l}\text { Before the start of the day / week I } \\
\text { make a to-do list }\end{array}$} \\
\hline \multicolumn{7}{|l|}{$\begin{array}{l}\text { I do not late for job / study / } \\
\text { various activities }\end{array}$} \\
\hline \multicolumn{7}{|c|}{\begin{tabular}{l|l} 
I delegate to others tasks that are & \\
not important to me &
\end{tabular}} \\
\hline \multicolumn{3}{|c|}{ Markers of self-management skills } & \multicolumn{2}{|c|}{ Yes } & \multicolumn{2}{|c|}{ No } \\
\hline \multicolumn{3}{|c|}{ I am confident in life and have a high self-esteem } & & & & \\
\hline \multicolumn{7}{|c|}{ I exercise regularly or do sports } \\
\hline \multicolumn{7}{|c|}{ I follow the principles of healthy eating / dieting } \\
\hline \multicolumn{7}{|c|}{ There is a well-organized order on my desktop } \\
\hline \multicolumn{7}{|c|}{ I wake up on weekdays and weekends at the same time } \\
\hline \multicolumn{7}{|c|}{ I write down my goals and ways to achieve them } \\
\hline \multicolumn{7}{|c|}{ I don't spend time on TV and social media } \\
\hline \multicolumn{7}{|c|}{ I haven't any debts and outstanding loans } \\
\hline \multicolumn{3}{|c|}{ Markers of communication skills } & Yes & Sometim & & No \\
\hline \multicolumn{3}{|c|}{$\begin{array}{l}\text { You have a scheduled regular business meeting. Are } \\
\text { you worried? }\end{array}$} & & & & \\
\hline \multicolumn{3}{|c|}{$\begin{array}{l}\text { Do you feel yourself embarrassed with the assignment } \\
\text { to make a report, message, information at any meeting } \\
\text { or other similar event? }\end{array}$} & & & & \\
\hline \multicolumn{3}{|c|}{$\begin{array}{l}\text { Do you postpone a visit to the doctor until the last } \\
\text { moment? }\end{array}$} & & & & \\
\hline \multicolumn{3}{|c|}{$\begin{array}{l}\text { You are offered to go on business to a city you have } \\
\text { never been to. Will you do all efforts to avoid this trip? }\end{array}$} & & & & \\
\hline \multicolumn{3}{|c|}{ Do you like to share your feelings with anyone person? } & & & & \\
\hline \multicolumn{3}{|c|}{$\begin{array}{l}\text { Are you annoyed if some stranger suddenly asks you to } \\
\text { show the way / some question? }\end{array}$} & & & & \\
\hline \multicolumn{3}{|c|}{$\begin{array}{l}\text { Are you afraid to take part in solving of conflict } \\
\text { situations? }\end{array}$} & & & & \\
\hline
\end{tabular}


The results of assessing students' communication skills before studying the training course showed that before studying the course $21.3 \%$ of respondents had a low level of communication skills, 35.5\% of students had an average level, $43.3 \%$ had a high level of communication skills. After studying the course and re-testing, $50.3 \%$ of students who took the «Training Soft Skills» course had a high level of communication skills, an average level of $33.1 \%$, and a low level of only $16.6 \%$ of students.

Thus, the introduction of a special training course with Soft Skills for university students has demonstrated a fixed effectiveness. The present soft skills assessment tool can also be used to assess students' flexible social skills as part of the study of other disciplines. Prospective research will be devoted to the analysis of the level of formation of students 'and students' cognitive skills: critical, reflective, systems thinking, complex problem solving.

\section{References:}

1. Bernadette Wightman (2020). Hundreds of millions of workers need reskilling. Where do we start? Global Agenda / Education and Skills / Davos 2020 / Future of Work. Retrieved from: https://www.weforum.org/agenda/2020/01/hundreds-ofmillions-of-workers-need-reskilling-where-do-we-start?fbclid=IwAR1FojgyKgF7ACg 8QJp_zWUNKywfdLieP45-_7c3IdcDMw8vt634Ijn3Y_s (accessed 9 September 2020).

2. Jürgen Hagmann and Conny Almekinders, with Christopher Bukenya, Francisco Guevara, Aklilu Hailemichael, Prossy Isubikalu, Geoffrey Kamau, Bernard Kamanga, Paul Kibwika, Budsara Limnarankul, Francis Matiri, Tendayi Mutimukuru, Hlamalani Ngwenya, Chris Opondo, Lanying Zhang, and Ulrike Breitschuh (2003). Developing 'soft skills' in higher education. Pla notes 48. December X. Retrieved from: https://www.researchgate.net/publication/287651618 (accessed 9 September 2020).

3. Serhut Kurt (2018). Kirkpatrick Model: Four Levels of Learning Evaluation. Retrieved from: https://educationaltechnology.net/kirkpatrick-model-four-levelslearning-evaluation/ (accessed 11 September 2020).

4. Shaulska, L. V, Sereda, G. V., \& Shkurat, M. Y. (2015). The Development of Soft Skills in the Provision of Competitiveness of Graduates. Economic Herald of the Donbass, vol. 4, no. 42, pp. 177-181. 